\title{
Innovative milieu, micro firms and local development in Barcelona
}

\section{Josep Lladós*}

Economic and Business Department

and

Internet Interdisciplinary Institute (IN3)

Universitat Oberta de Catalunya (UOC)

Avda. Tibidabo, 39-43, 08035 Barcelona, Spain

E-mail: jlladosm@uoc.edu

*Corresponding author

\section{Mireia Fernández-Ardèvol}

Internet Interdisciplinary Institute (IN3)

Universitat Oberta de Catalunya (UOC)

Avda. Tibidado, 47, 08035 Barcelona, Spain

E-mail: mfernandezar@uoc.edu

\section{Jordi Vilaseca}

Economic and Business Department

and

Internet Interdisciplinary Institute (IN3)

Universitat Oberta de Catalunya (UOC)

Rambla del Poblenou, 156, 08018 Barcelona, Spain

E-mail: jvilaseca@uoc.edu

\begin{abstract}
An entrepreneurial environment is conformed by factors that play a favourable role in the development of entrepreneurship. Economic literature on innovative milieus identifies those elements that are decisive in improving the competitive performance of companies. We analysed whether Barcelona Activa's specific environment promotes the development of an innovative milieu, which favours entrepreneurial attitudes. The results show how the combination of incubation experience, development of ICT-based innovations and cooperation considerably improve the success probability of new firms. Moreover, participation in institutional activities that strengthen commercial and social networks also improves their chances. The local agency seems to be particularly suitable for entrepreneurs with labour experience and it plays a complementary role in the framework of the wide range of university spin-off centres in the metropolitan region.
\end{abstract}

Keywords: milieu; innovation; entrepreneurship; network; Information and Communications Technology; ICT; business success; Barcelona.

Reference to this paper should be made as follows: Lladós, J., Fernández-Ardèvol, M. and Vilaseca, J. (xxxx) 'Innovative milieu, micro firms and local development in Barcelona', Int. J. Entrepreneurship and Small Business, Vol. X, No. Y, pp.000-000. 
Interdisciplinary Internet Institute or Internet Interdisciplinary Institute?
Interdisciplinary Internet Institute or Internet Interdisciplinary Institute?
Biographical notes: Josep Lladós has as Bachelor's degree in Economics and Business and a Postgraduate degree in Local Finance and Economics from the University of Barcelona, Spain. Since 2000, he has been a Professor in the Economics and Business Department of the Universitat Oberta de Catalunya (UOC) and a Researcher at the Interdisciplinary Internet Institute (IN3). At present, he is the Vice-Rector for the Faculty and Academic Organisation at UOC. He is the author of a wide number of learning resources, as well as several books and articles about knowledge economy and regional economics. He has also contributed to different European research projects. He currently carries his research work in the fields of innovation and entrepreneurship.

Mireia Fernández-Ardèvol graduated in Business Administration and in Economics from the University of Barcelona, Spain. She obtained her Master diploma in 2000 on the PhD Programme in Quantitative Techniques Applied to Economics at the same university. She carries out her research work with the IN3 in two different fields: entrepreneurship and small business and the socioeconomic impact of mobile communications. She is currently working on her $\mathrm{PhD}$ thesis, which is devoted to the first field.

Jordi Vilaseca has a Bachelor's degree in Economics and Business from the University of Barcelona, Spain. He also has a Master degree in Public Policy from the United Nations. He is a Professor in the World Economic Structure and Economic Policy Department of the University of Barcelona. Since 1997, he has been a Professor of Economics in the Economics and Business Department of the Universitat Oberta de Catalunya. He is the Director of the New Economy Observatory (ONE) research group, attached to the Internet Interdisciplinary Institute (IN3-UOC). At present, the group conducts a number of research projects on information technologies, companies communications, economy and the knowledge society.
Please clarify highlighted

\section{Introduction}

Usually, an entrepreneur does not drive her/his idea to the market in isolation. In fact, several factors play a key role in the development of entrepreneurship (see for instance, Wagner and Sternberg, 2004). The combination of all them determines the so-called entrepreneurial environment. On the one hand, this environment refers to the overall economic, sociocultural and political factors that influence people's willingness and ability to undertake entrepreneurial activities. On the other, it refers to the availability of assistance and support services that facilitate the start-up process (Gnyawali and Fogel, 1994; Muller and Fujiwara, 2003; Feldman et al., 2005). Obviously, public policy can shape this environment and can also affect the environmental conditions for entrepreneurship.

However, entrepreneurship rates differ widely among regions that have otherwise similar conditions. In addition to political and local characteristics, some other essential points explain why some communities are more adept at recognising and exploiting economic opportunities. As far as economic activity tends to cluster geographically, entrepreneurship also tends to concentrate. Traditionally, increasing returns are identified as the main reason for this concentration. However, numerous political initiatives encouraging entrepreneurial activities by means of science parks have failed (Löfsten and Lindelöf, 2003). Therefore, we have to look also at the significance of the local social 
environment (Aldrich and Fiol, 1994). As Minniti (2005) points out, when proper social networks are in place, agglomeration works and follows the form and patterns identified by the new economic geography literature.

The economic literature on innovative environments identifies the presence of a set of elements that are decisive in improving the competitive performance of the firms that belong to it: a particular geographical area, a set of actors, several tangible, intangible and institutional common elements; and even more important, the ability to share an organisational logic, a learning system and a relational culture (Aydalot, 1986a; Aydalot, 1986b; Maillat, 1988; Maillat, 1992). The main objective of our research is to identify the presence and intensity of those elements among the entrepreneurs that develop their new firms with the support of Barcelona Activa (BA), the local development agency of the Barcelona City Council (Solé, 1987).

\section{Conceptual framework}

A distinctive factor of an innovative milieu, as defined by Groupe de Recherche Européen sur les Milieux Innovateurs (GREMI) is the significance of social capital on the innovation process. In particular, the development of relational networks is based on confidence, formalised in cooperative innovation projects and geared towards generating and disseminating knowledge. In this sense, and given that our research is about new companies, we opt for analysing the entrepreneurs' perception of their interactions with the environment created by BA. This environment necessarily exceeds the frontiers of incubation spaces, adding other successful companies that recently left the incubation centre as well as companies attracted by the institutional networking initiatives.

In practice, and in addition to economic variables, the social environment is also an important cause of agglomeration. In fact, one of the specificities of an innovative milieu is the significance of social capital on encouraging innovation. These social networks are established between individuals inside the company and between individuals in different firms. As the sample we are analysing is made up of new firms, understanding the innovative environment requires an in-depth investigation of the content of a company's relational network and also, obviously, of its innovation activity. Usually, social networks are the result of a situation of mutual confidence that is based on the long experience of common goals and shared work developed in the past between firms and/or institutions. As we are talking about very young firms, we also have to consider the entrepreneurs' perception or recognition of their interaction with the milieu. Moreover, the milieu analysis should necessarily go beyond the incubation centres to incorporate both the successful companies that have left the incubators and other firms attracted by the institutional networking programme.

In this environment, companies make use of shared innovation projects and get involved in collective learning processes that promote creativity and innovation, both from formal agreements and from the constant and informal exchange of information and specific knowledge - a set of 'non-traded' relationships. As Camagni (1991) points out:

"The local milieu provide the economic background and elements of continuity on which learning processes and tacit information transfer become embedded and accumulate over time, playing the same role as R\&D departments and corporate culture in the case of large firms." 
Usually, they are made up of companies that offer specialised and highly qualified labour. For them, innovation is the strategic asset for competitiveness, so that entrepreneurs are continuously carrying out strategic cooperative agreements to share the typical goals and objectives linked to the development of innovations.

Therefore, the success of the innovation process also depends on the temporal, spatial and organisational context of companies (Porter, 1990). As technological and commercial complexity grows, the innovation process is understood more as a cooperative activity than an individual one. The spatial dimension of innovation is important so long as throughout the European Union we can observe a wide regional dispersion in innovation propensity, even in the age of digital revolution (Porter and Stern, 2001; Audretsch, 2004). However, it does not mean that in all the leading regions there is a cluster of innovative and highly interactive companies. Although innovation is the foreseeable outcome of an interactive learning process, which frequently implies the exploitation of several internal and external resources, proximity between them is not indispensable for making innovation possible (Lockett et al., 2005). As a consequence, economic literature on innovation identifies a wide diversity of local productive systems.

Camagni and Capello (1999) point out that regions with very different business structures show similar innovation rates. They also confirm that localisation economies, which characterise industrial districts, do not necessarily drive innovation because productivity does not depend on the specialisation or size of companies. In practice, innovation capabilities are related both to internal resources and to a milieu effect. This effect would be the consequence of using some type of $c l u b$ information that benefits the innovation process and results from the interaction with their specific environment.

Therefore, we would expect that the local milieu plays a very important role in promoting innovation by means of two different forces:

1 a shared learning system that reinforces local creativity and promotes knowledge diffusion

2 a common relational and organisational culture that benefits the development of innovations based on cooperation and decreases the risks and uncertainties inherent to innovation.

\section{Methodology}

Although the analysis unit of the process of innovation are the companies, generally highly qualified labour is the main driving force in creating and disseminating new knowledge. When these kinds of workers appropriate the fruits of the new ideas and knowledge they generate, then they become potential entrepreneurs. This stimulus would probably be stronger if the market value of the potential entrepreneur's ideas were much higher than the wage he receives, or if a company's mechanisms for retaining talent work poorly.

In these start-up cases, the process of innovation in the new firm would depend on the knowledge embedded in the entrepreneur, and the wide diversity of new organisational structures enabled by using ICT would encourage this process (Audretsch, 2002; Maillat and Lecoq, 1992). As a consequence, the aim of our research is to investigate, on the one hand, whether BA's programmes and activities not only offer economic advantages to 
entrepreneurs, but also effectively promote the development of an innovative milieu and, on the other, if this specific environment encourages innovations based on the strategic use of digital technologies by entrepreneurs.

The fieldwork consisted of a combination of complementary techniques, both qualitative and quantitative, and was carried out over a one-year period (April 2005 to April 2006). From a qualitative point of view, we conducted 22 in-depth interviews with entrepreneurs belonging to the core network of BA. Six of them were subsequently used in the questionnaire design, while the rest served for confirmatory purposes. Moreover, the research team held seven interviews with different key staff members of Barcelona Activa. Finally, a total of three different focus groups were held. In them, entrepreneurs and experts discussed financing entrepreneurship, innovation and training, and networking and e-commerce.

For the quantitative analysis we conducted a survey among the population of entrepreneurs who lead a company that usually interacts with BA, a group that we define as the core network of Barcelona Activa (256 individuals); that is, those that could be considered part of the environment created by BA. The questionnaire was administrated by e-mail, with a $52.4 \%$ response rate of the population under study (136 questionnaires). Under the hypothesis of a random sample, this would mean a precision of $+/-4.87 \%$ for a situation of maximum uncertainty $(\mathrm{p}=\mathrm{q}=0.5)$ and a confidence level of $95 \%$.

Two subgroups were also analysed. One corresponds to those companies currently located in BA incubator, with a population of 49 firms. With a response rate of $91.8 \%$ (45 questionnaires), the achieved precision would be $+/-2.54 \%$ in the terms already stated. Meanwhile, the group of companies that started up in the BA incubator comes to a total of 101 firms which, either currently or in the past, have been located in BA's incubator. The response rate was $80.2 \%$, a figure which would mean a precision of $+/-4.09 \%$.

This response rate falls within the usual limits of online surveys (among others, see Heerwegh and Loosveldt, 2006), as well as those of postal surveys (see for instance Ucbasaran et al., 2006; Galende del Canto and de la Fuente, 2003; Cowling, 2003). To encourage the response, an institutional e-mail was sent introducing the research. Respondents had the choice of answering the survey in Catalan or Spanish. The tool allows multiple consistency controls that guarantee the quality of the data and prevent respondents from answering more than one questionnaire.

\section{Entrepreneurs and enterprises belonging to the core network of Barcelona Activa}

In this section we describe the main characteristics of companies and entrepreneurs belonging to the core network of Barcelona Activa (BA). Both present distinctive features that differentiate them from the Catalan average.

These companies develop their activity in the city of Barcelona, the main demographic and economical engine of the country. According to the data provided by the city council (Ajuntament de Barcelona, 2007), with only the $22.5 \%$ of the Catalan population (1.6 million inhabitants in 2006), the gross domestic product of the city rises up to the $30.5 \%$ of the Catalan economy (last data available referred to 2001). In 2005, there were almost 11 companies per 100 inhabitants, with the Small and Medium 
Enterprises (SMEs) representing the $99.7 \%$ of the total. They create the $67.3 \%$ of the employment and the $66.4 \%$ of the gross added value in the city. In fact, Barcelona becomes the leader city of a very entrepreneur region, in the European context (Global Entrepreneurship Monitor, 2006).

Investigated companies of our sample are quite young. Their average age is less than five years with up to $25 \%$ of them having started the activity during the preceding 12 months. A significant part of them were incubated by Barcelona Activa (59.6\%), while the youngest ones still remain there (33.1\% of the total population under study). With an average of 5.7 full-time workers, who in most cases hold a university degree $(80.9 \%)$, these companies' activities are mainly in the Information and Communication Technologies sector $(39.7 \%)$ and in business services $(25.0 \%)$. These profiles, indeed, respond to the target and goals defined by the local development agency.

Table 1 Companies and entrepreneurs - selected indicators

\begin{tabular}{|c|c|c|c|}
\hline Companies & Percentage & Entrepreneurs & Percentage \\
\hline Average age (years) & 4.5 & Average age (years) & 39 \\
\hline Incubated in BA & 59.6 & Men & 61.8 \\
\hline Currently in the BA incubator & 33.1 & Women & 38.2 \\
\hline \multirow[t]{2}{*}{ Never part of the incubator } & & Spanish & 94.8 \\
\hline & & Of whom: Catalan & 89.9 \\
\hline $\begin{array}{l}\text { Average number of workers } \\
\text { (Full time or equivalent) }\end{array}$ & 5.7 & $\begin{array}{l}\text { Entrepreneurs holding a } \\
\text { university degree }\end{array}$ & 85.3 \\
\hline $\begin{array}{l}\text { Companies in which the majority of } \\
\text { workers hold a university degree }\end{array}$ & 80.9 & $\begin{array}{l}\text { Parent(s) or grandparent(s): } \\
\text { business owner(s) }\end{array}$ & 68.4 \\
\hline Sector & & Previous situation: & \\
\hline Information and Communications & 39.7 & Unemployed & 10.3 \\
\hline Technology (ICT) & 25.0 & Wage earner & 59.6 \\
\hline Business services & & & \\
\hline \multicolumn{4}{|l|}{ Start-up financial resources } \\
\hline Personal savings & 74.3 & & \\
\hline Financial borrowing & 22.8 & & \\
\hline Capital risk & 4.4 & & \\
\hline \multicolumn{4}{|l|}{$\begin{array}{l}\text { Average gross annual wage } \\
\text { per employee }\end{array}$} \\
\hline$<18,000$ EUR & 27.2 & & \\
\hline 18,000-24,000 EUR & 40.4 & & \\
\hline$>24,000$ EUR & 16.2 & & \\
\hline Companies that export & 41.2 & & \\
\hline $\begin{array}{l}\text { High Business Success } \\
\text { (HBS) indicator }\end{array}$ & 46.3 & & \\
\hline $\begin{array}{l}\text { High Quality Job Creation } \\
\text { (HQJC) indicator }\end{array}$ & 33.1 & & \\
\hline
\end{tabular}


Businesses were mainly financed with the entrepreneurs' personal savings $(74.3 \%$ of cases) and by means of financial borrowing $(22.8 \%)$, while capital risk operations were scarce $(4.4 \%)$. These figures are a clear reflection of the general conditions of the Spanish loan market (Ontiveros et al., 2005). At present, $40.4 \%$ of the companies pay annual gross wages per employee of between 18,000 and 24,000 EUR while an outstanding $16.2 \%$ pays over 24,000 EUR. It should be noted that the Catalan average annual net wage was 17,846 EUR in 2003 , while the median net wage was 15,970 EUR (Vilaseca, 2003). ${ }^{1}$

Export rates were not very high, with less than half of the enterprises entering international markets (41.2\%), whereas their performance is quite good insofar as $46.3 \%$ of them would be classified as a highly successful company while one out of three $(33.1 \%)$ creates high quality jobs. At this point, it is worth commenting how these two last figures were obtained.

The first figure corresponds to the High Business Success (HBS) Indicator, which is a dummy variable taking the value of one when the next conditions are met:

- The company expects profits in the year of the survey.

- Both the expected turnover and the number of full-time employees increase with respect to the previous year, or one of the two increases while the other remains constant.

The second corresponds to the High Quality Job Creation (HQJC) Indicator, which is also a dummy variable taking the value of one when:

- The company pays medium-high salaries, that is, the average gross wage per employee equals or exceeds 18,000 EUR per year.

- The company shows a positive one-year evolution in the total number of full-time employees.

Furthermore, it should be noted that the HBS indicator could be considered a short-term business performance measure, while the HQJC would better capture the medium-term performance because it is more focused on what could be the structural responses to market fluctuations.

With respect to the features of the members of the BA network, it was observed that they are quite young (39, on average) and created the business in their thirties $(34$, on average). Entrepreneurs are mostly men $(61.8 \%)$ with at least a university degree in most cases $(85.3 \%)$. This last figure is higher than the average of managers of Catalan companies, a group in which only $53.1 \%$ hold a university degree (Vilaseca, 2003), and substantially higher than the adult Catalan average (12.4\%, following Castells et al., 2003). On the other hand, the uneven gender balance would be rooted, among other reasons, in the different backgrounds between genders, with a higher presence of technicians among men (see, for instance, Ministerio de Educación y Ciencia, 2005). Almost all of the entrepreneurs in the network are Catalan or Spanish (94.8\%), with most of them belonging to a family where an elder relative has, or had, their own business $(68.4 \%)$. 
Finally, the presence of previously unemployed entrepreneurs is not very high (10\%), while it can be observed that those supported by Barcelona Activa are better at taking advantage of the available instruments and resources to finance the start-up process (for instance, the capitalisation of unemployment benefit).

\section{The scope and influence of the innovative milieu}

In order to better appreciate the scope of the innovative environment, we built two variables that gather, on the one hand, the entrepreneur's perception of the innovative environment; and, on the other, the innovative behaviour of the firm he or she owns. Their combination will allow the identification of three different firm profiles.

In order to build the Perception of the Innovative Environment indicator, five subjective considerations were taken into account. By adding them we obtain an indicator with values from 0 to 5 , as all of them were dummy variables - taking the value of 1 when the characteristic is present and 0 otherwise. These five components were:

1 the entrepreneur regards BA staff as an agent of innovation

2 Xarxactiva, the network created and managed by BA, favours the development of strategic alliances

3 Xarxactiva is a mechanism for knowledge dissemination

4 the experience of cooperation with BA allows an entrepreneurial environment to be shared with other firms

5 this interaction generates a common shared culture.

Following the same methodology, the Innovative Behaviour indicator also takes values from 0 to 5 . In this case, the dummy variables were:

1 if the firm develops ICT-based innovations

2 if it has established strategic alliances with other firms located in BA's facilities

3 there are knowledge generation and dissemination links with these firms

4 if the firm has established cooperation agreements in order to develop innovations

- with suppliers, clients or scientific institutions

5 if it develops economic activities with competitors.

By separating the variables into two categories, it can be observed that innovative perception is higher than innovative behaviour (see Table 2) whereas the medium-high level is a minority in both cases (43.3\% and $36.0 \%$, respectively). Moving on, it is precisely the combination of these two categories that leads us to identify the three different profiles of firms that will allow the scope and effects of the innovative milieu to be evaluated. The names we have given to these profiles are: Milieu Effect, Milieu Seeker and Milieu Unaware. 
Innovative milieu, micro firms and local development in Barcelona

Table 2 Innovative perception and innovative behaviour

\begin{tabular}{|c|c|c|}
\hline Level & $\begin{array}{c}\text { Perception of } \\
\text { innovative environment (\%) }\end{array}$ & Innovative behaviour (\%) \\
\hline Medium-high level (3-5) & 43.3 & 36.0 \\
\hline Medium-low level (0-2) & 56.7 & 64.0 \\
\hline
\end{tabular}

In the first place, to be in the Milieu Effect category, a firm must show a medium-high level of innovative behaviour and its leader must show a medium-high perception of innovative environment. This group represents $22.1 \%$ of the whole population under study, being most important within the group of firms that were brought up in BA's incubator and now have an alternative location (see Table 3). In the second place, the Milieu Seeker category encompasses those cases with medium-low innovative behaviour and medium-high innovative perception. With a similar importance in the whole population $(21.3 \%)$, it is mainly found among firms which were never part of BA's incubators (30.9\%). Finally, the Milieu Unaware category groups those cases in which innovative behaviour is medium-high whereas perception remains medium-low. Its weighting is low (14.0\%), but most can be found among those companies currently located in BA's incubator $(20.0 \%)$. In turn, these profiles identify three different types of companies.

Table 3 Use of the innovative environment in the sample

\begin{tabular}{lccc}
\hline & \multicolumn{3}{c}{ Percentage of firms } \\
\cline { 2 - 4 } Companies, by location & $\begin{array}{c}\text { Milieu } \\
\text { effect }\end{array}$ & $\begin{array}{c}\text { Milieu } \\
\text { seeker }\end{array}$ & $\begin{array}{c}\text { Milieu } \\
\text { unaware }\end{array}$ \\
\hline Whole sample & 22.1 & 21.3 & 14.0 \\
Currently located in BA's incubator & 22.2 & 13.3 & 20.0 \\
Not now, but previously located in BA's incubator & 36.1 & 16.7 & 8.3 \\
Never part of BA's incubator & 12.7 & 30.9 & 12.7 \\
\hline
\end{tabular}

Firms with a Milieu Effect profile are the most likely to show innovative forms of growth, both within a group or in a network (Table 4). Their most common strategy is based on product differentiation, whereby they are the most frequent users of the internet for commercial purposes. Indeed, better use of the environment is distinctly related to the presence of good performance levels, as long as both the HQJC and the HBS indicators stay above the total population average and above the rest of the profiles under study.

Companies with a Milieu Seeker profile are in a consolidation stage (Table 4). They face some difficulties in developing their business as well as in their competitive position. Their low presence in international markets is accompanied by lower success levels as well as product differentiation weaknesses. They almost never use the internet for commercial purposes; nor have they manifested any innovative forms of growth. All these facts lead to very discrete global performance indicators (HQJC and HBS). However, they rate interaction with BA's environment very highly. And what is most important, given their weaknesses, they expect to improve their market success possibilities by taking the most advantage of the networking and knowledge transfer mechanisms provided by the environment. 
Table 4 Use of the innovative environment and company development

\begin{tabular}{|c|c|c|c|c|}
\hline \multirow[b]{2}{*}{ Characteristics of the company } & \multicolumn{3}{|c|}{ Percentage of firms } & \multirow{2}{*}{$\begin{array}{c}\text { Total } \\
\text { sample } \\
(\%)\end{array}$} \\
\hline & $\begin{array}{c}\text { Milieu } \\
\text { effect }\end{array}$ & $\begin{array}{l}\text { Milieu } \\
\text { seeker }\end{array}$ & $\begin{array}{c}\text { Milieu } \\
\text { unaware }\end{array}$ & \\
\hline \multicolumn{5}{|l|}{ Competitive strategy } \\
\hline Cost leadership & 20.0 & 28.6 & 5.3 & 20.7 \\
\hline Product differentiation & 50.0 & 17.9 & 52.6 & 40.7 \\
\hline Specialisation & 30.0 & 53.6 & 42.1 & 38.5 \\
\hline \multicolumn{5}{|l|}{ Market openness } \\
\hline Developing export activities & 43.3 & 24.1 & 47.4 & 41.2 \\
\hline Sales in non-local markets & 63.3 & 55.2 & 63.2 & 63.2 \\
\hline E-commerce sales & 43.3 & 17.2 & 21.1 & 30.9 \\
\hline \multicolumn{5}{|l|}{ Growth strategy } \\
\hline $\begin{array}{l}\text { Growth strategy by means of new products } \\
\text { and new markets }\end{array}$ & 33.3 & 31.0 & 5.3 & 27.2 \\
\hline $\begin{array}{l}\text { Growth strategy by means of } \\
\text { strategic alliances }\end{array}$ & 20.0 & 24.1 & 0.0 & 14.7 \\
\hline $\begin{array}{l}\text { Growth strategy by means of creating } \\
\text { a group }\end{array}$ & 20.0 & 6.9 & 0.0 & 7.4 \\
\hline Growth strategy by means of a network & 20.0 & 6.9 & 5.3 & 8.1 \\
\hline \multicolumn{5}{|l|}{ Performance } \\
\hline High Quality Job Creation (HQJC) & 43.3 & 17.2 & 31.6 & 33.1 \\
\hline High Business Success (HBS) & 63.3 & 24.1 & 47.4 & 46.3 \\
\hline
\end{tabular}

Finally, the Milieu Unaware profile encompasses a group with a very low propensity to interact with BA's environment. Conversely, these firms show a high performance, good market position, significant innovation levels supported by ICT use and, in some cases, high export rates (Table 4). However, they do not develop innovative growth strategies while their performance indicators remain rather average. Despite the fact that a significant number of them are part of the incubator, firms in this group do not take advantage of BA's environment opportunities, probably because, in their present situation, they do not perceive any benefit.

\section{Determining factors of entrepreneurial success}

We developed three different models in order to explain the way entrepreneurs reach the highest levels of performance. The first one (Figure 1) is based on the evidence of the positive role that incubators play in the life expectancy of start-up businesses (relating to Spain and Catalonia, see Gómez, 2002; EdAS, 2004; Urbano, 2005). In this context, the goal of the model is to identify some of the mechanisms involved in achieving a good short-term performance when a company has been incubated in Barcelona Activa.

Incubator experience positively influences three intervening variables. Two of them are related to networking both inside and outside the institutional sphere of influence managed and created by Barcelona Activa: having links with companies located in 
facilities provided by Barcelona Activa; and establishing cooperation activities with agents outside the Barcelona Activa network. On the other hand, to a lesser degree it also favours the innovative dynamism of the company (put simply, the introduction of innovations through the use of ICT). Furthermore, networking encourages innovation, given that the two variables already seen have a positive and similar influence on the innovative dynamism of the company. In the last part of Model 1, it can be observed that the highest direct influence on the HBS indicator is due to the innovative dynamisms of the firm, while networking variables show a minor direct effect. ${ }^{2}$

Arrows indicate lineal causality relationships. Coefficients can be interpreted as the direct influence of one variable on the variable the arrow points to. The goal of this methodology is to determine the effect of each of the explanatory variables (exogenous and intervening) on the endogenous variable of the model. In model 1 , the exogenous variable is Incubator Experience. There are three intervening endogenous variables: links with companies located in facilities provided by Barcelona Activa; innovative dynamism (the company has introduced innovations through the use of ICT); cooperation with agents outside the Barcelona Activa network. Finally, the endogenous variable is the HBS indicator. The accounting of direct and indirect effects is shown in Table 5.

Figure 1 Model 1. Path from incubator experience to HBS

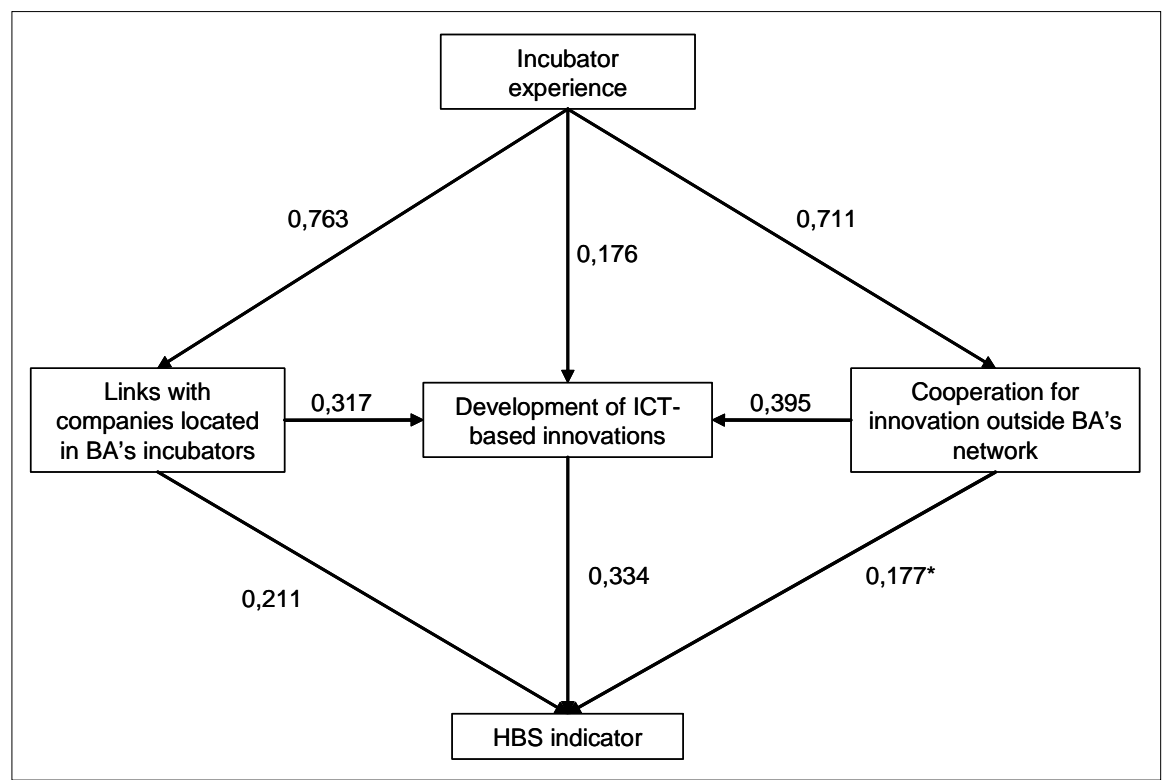

Notes: $\quad$ Total number of observations: 136.

*Significant parameter at the $10 \%$ level. All the other parameters are significant at the 5\% level. 
Table 5 Accounting for effects on HBS in model 1

\begin{tabular}{|c|c|c|c|}
\hline Exogenous variable & Direct effect & Indirect effect & Total effect \\
\hline Incubator experience & 0.000 & 0.512 & 0.512 \\
\hline \multicolumn{4}{|c|}{ Incubator experience favours high business success in $51.2 \%$} \\
\hline \multicolumn{4}{|l|}{ Networking variables } \\
\hline $\begin{array}{l}\text { Links with companies } \\
\text { located in BA's incubators }\end{array}$ & 0.211 & $0.106^{2}$ & 0.317 \\
\hline \multicolumn{4}{|c|}{$\begin{array}{l}\text { The existence of links with companies outside Barcelona Activa favours high business success } \\
\text { in } 31.7 \%\end{array}$} \\
\hline $\begin{array}{l}\text { Cooperation for innovation } \\
\text { outside BA's network }\end{array}$ & $0.177 *$ & $0.132^{3}$ & 0.309 \\
\hline \multicolumn{4}{|c|}{$\begin{array}{l}\text { Cooperation with agents that do not belong to the Barcelona Activa network favours high busines } \\
\text { success in } 30.9 \%\end{array}$} \\
\hline \multicolumn{4}{|l|}{ Innovation variable } \\
\hline $\begin{array}{l}\text { Development of } \\
\text { ICT-based innovations }\end{array}$ & 0.334 & 0.000 & 0.334 \\
\hline \multicolumn{4}{|c|}{ Innovative dynamism favours high business success in $33.4 \%$} \\
\hline $17 * 0.334$ & $\begin{array}{l}7 * 0.334)+0 \\
10 \% \text { level. }\end{array}$ & $711 * 0.395 * 0$ & \\
\hline
\end{tabular}

Summing up, the model demonstrates how three elements shape the path to high business success. Incubation favours all of them which, in turn, fosters good performance levels through direct and indirect paths. Thus networking, both inside and outside the Barcelona Activa sphere, leads to good levels of business performance through the innovative dynamism of the company, which is the variable that most directly influences the endogenous variable of the model.

The aim of Model 2 (Figure 2) is to account for the effects of the Milieu Effect variable on the HQJC Indicator. Being an entrepreneur aware of the benefits of an innovative environment and taking advantage of it favours a positive influence on the company's performance. Having a Milieu Effect profile directly favours high business success, while its positive influence on the creation of high quality jobs is strongly mediated by the HBS indicator (see Table 4). Thanks to that simple model it can be seen that if this mediation were not taken into account, the relationship between the two variables would have been reported as a weak relationship only significant at the $10 \%$ level.

The exogenous variable in Model 2 is the Milieu Effect, as defined previously. There is only one intervening endogenous variable, the HBS indicator, the endogenous is HQJC indicator. Effects on the endogenous are shown in Table 6. 
Figure 2 Model 2: Creation of HQJC

Notes: Total number of observations: 136.

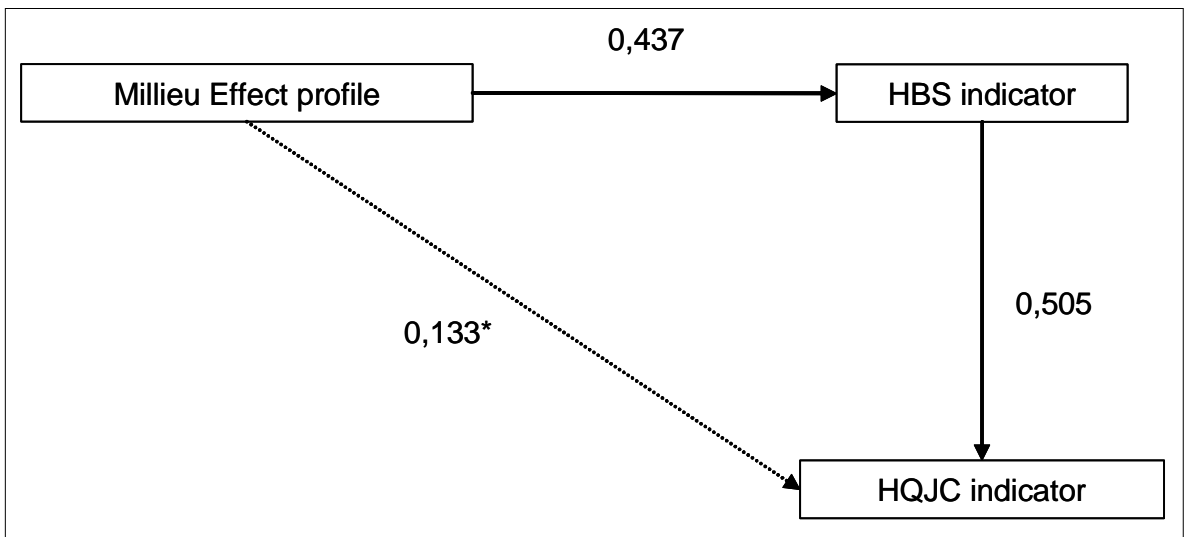

*Significant parameter at the $10 \%$ level. All the other parameters are significant at the $5 \%$ level.

Table 6 Accounting for effects on HQJC in Model 2

\begin{tabular}{lccc}
\hline Exogenous variable & Direct effect & Indirect effect & Total effect \\
\hline $\begin{array}{l}\text { Milieu effect profile } \\
\text { Medium and high innovative perception and behaviour favours the creation of high quality jobs } \\
\text { in 35.4\% }\end{array}$ & $0.133^{*}$ & $0221^{1}$ & \\
\hline Short term performance & 0.505 & 0.000 & 0.505 \\
\hline $\begin{array}{l}\text { High Business } \\
\text { Success Indicator }\end{array}$ & & \\
Presenting high business success favours the creation of high quality jobs in 50.5\% & \\
\hline
\end{tabular}

Notes: $\quad{ }^{1}=0.437 * 0.505$.

*Significant parameter at $10 \%$ level.

Model 3 focuses on those entrepreneurs who make the most of Barcelona Activa (Figure 3). In this sense, it can be observed that participation in start-up programmes offered by the institution directly favours two personal characteristics which are, in order of intensity, being a wage earner before the creation of the current company and having previous experience in business creation. In turn, both positively encourage the active membership of Xarxactiva, a network created by Barcelona Activa. It should be noted that, again, the intensity is higher among those who were wage earners previously. Finally, as can be expected, networking (active membership of Xarxactiva) has a positive influence on high business success.

The exogenous variable now is consumption of BA's start-up programmes. There are three intervening endogenous variables:

1 entrepreneur experienced in business creation

2 previous situation: wage earner

3 active member of Xarxactiva. 
Finally, the endogenous variable is the HBS indicator. The effects of the variables on HBS are shown in Table 7.

Figure 3 Model 3: Entrepreneurs' path to high business success (HBS)

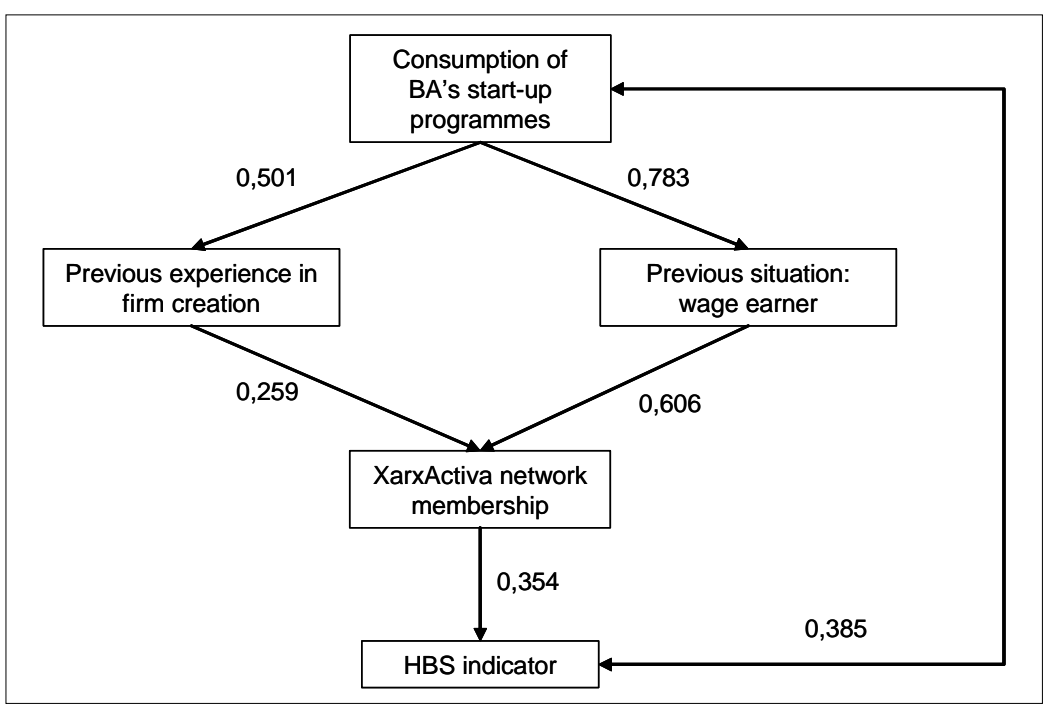

Notes: Total number of observations: 136 .

All the parameters are significant at the 5\% level.

Table 7 Accounting for effects on High Business Success (HBS) in Model 3

\begin{tabular}{|c|c|c|c|}
\hline Exogenous variable & Direct effect & Indirect effect & Total effect \\
\hline $\begin{array}{l}\text { Consumption of BA's } \\
\text { start-up programmes }\end{array}$ & 0.385 & $0.214^{1}$ & 0.599 \\
\hline \multicolumn{4}{|c|}{$\begin{array}{l}\text { Participation in start-up programs and activities offered by Barcelona Activa facilitates business } \\
\text { success in } 59.9 \%\end{array}$} \\
\hline \multicolumn{4}{|l|}{ Personal features } \\
\hline $\begin{array}{l}\text { Previous experience in } \\
\text { creating firms }\end{array}$ & 0.000 & $0.092^{2}$ & 0.092 \\
\hline \multicolumn{4}{|c|}{ Having created more than one company facilitates business success in $9.2 \%$} \\
\hline $\begin{array}{l}\text { Previous situation: } \\
\text { wage earner }\end{array}$ & 0.000 & $0.215^{3}$ & 0.215 \\
\hline \multicolumn{4}{|c|}{ Being a wage earner before the creation of the company facilitates business success in $21.5 \%$. } \\
\hline \multicolumn{4}{|l|}{ Networking } \\
\hline $\begin{array}{l}\text { Xarxactiva network } \\
\text { membership }\end{array}$ & 0.358 & 0.000 & 0.358 \\
\hline \multicolumn{4}{|c|}{$\begin{array}{l}\text { Being an active member of the Xarxactiva network (environment variable) facilitates busine } \\
\text { success in } 35.8 \%\end{array}$} \\
\hline \multicolumn{4}{|c|}{$\begin{array}{ll}\text { Notes: } \quad{ }^{1}=0.501 * 0.259 * 0.354+0.783 * 0.606 * 0.354 & \\
& { }^{2}=0.259 * 0.354 \\
& { }^{3}=0.606 * 0.354\end{array}$} \\
\hline
\end{tabular}


It can be seen that the direct benefit obtained from the start-up programmes managed by Barcelona Activa is complemented when the entrepreneur has previous experience in the labour market. Given the fact that the average age is 39-years-old, this model shows that the target population of the institution consists of middle-aged entrepreneurs with previous experience, particularly those who were not self-employed.

\section{Conclusions}

From the point of view of a productive local system, as defined by GREMI, Barcelona Activa cannot be identified as an innovative milieu. However, from its actions and its interaction with entrepreneurs, we can deduce that it is contributing to the emergence of a significant innovation cluster which fosters entrepreneurial attitudes. In particular, some of the main results of our research are the following:

- Entrepreneurs who developed their business idea in the incubation centre show higher innovation intensity, specifically when these innovations are based on IT use.

- These entrepreneurs are also more prone to base their innovation process on cooperation.

- Wherever entrepreneurs locate their firm, there is significant recognition of BA as an innovation agent. As far as this perception is observed among all the defined segments analysed, the institutional role of BA as an innovation promoter would be proved.

To capture the scope of the innovation cluster, we built two synthetic indicators: the first one measures the entrepreneur's perception of the environment created by BA, while the other gathers the innovation performance of his company. Innovation intensity, development of strategic alliances, recognition of knowledge spillovers and cooperative innovation networks are some of the elements used to build these synthetic indicators.

From the crossed analysis of these two indicators, we collected some interesting evidence about what we define as the 'milieu effect'. In this sense, and despite the fact that the perception of an innovative cluster is higher than the actual innovation behaviour of the companies - neither of which are a majority in our sample - we detected some other noteworthy results:

- Companies created by those entrepreneurs that are more skilful in detecting and seizing the opportunities provided by the environment display higher profitability, greater export propensity and higher commercial use of the Internet. Moreover, these companies offer qualified, well-paid jobs.

- In general, these firms differentiate their services (or products) more in the market and they also show the most innovative growth strategies, mainly when these are based on groups, alliances or on network building.

- The 'milieu effect' is more alive among companies that have already left the incubation centre and among entrepreneurs with previous experience in entrepreneurial activities. 
- There is a short-sightedness effect among some entrepreneurs with companies, basically related to certain IT activities, which benefit from a market-niche but neither interact with their environment (other companies or innovation agents) nor achieve high economic success.

- Moreover, another group of companies with performance difficulties turns to Barcelona Activa to take advantage of their knowledge diffusion and networking mechanisms. Thanks to them, they finally manage to improve their capacities and success probabilities.

Finally, by means of a path analysis methodology, we are able to give a quantitative measurement of the effect of milieu on the chances of companies' market success; that is, improving their sales, obtaining profits and creating new jobs. Our results show how the combination of incubation experience, the development of ICT-based innovations and cooperation with other firms considerably improve this probability. In addition, participation in the programmes and services offered by BA also improve this probability, mainly when these activities strengthen the commercial and social networks and when those who benefit are entrepreneurs with labour experience. Therefore, for a metropolitan and regional economy with a large university base and a growing number of young graduates, as well as the development of spin-off centres in universities, it is also very important to support complementary policies that encourage start-up activities among wage-earning and highly qualified workers.

\section{References}

Ajuntament de Barcelona (2007) 'Anuari estadístic de la ciutat de Barcelona', http://www.bcn .cat/estadistica/catala/dades/anuari/index.htm (accessed October 2007).

Aldrich, H. and Fiol, M. (1994) 'Fools rush in? The institutional context of industry creation', Academy of Management Review, Vol. 19, No. 4, pp.645-670.

Audretsch, D.B. (2002) 'Entrepreneurship: a survey of the literature', Document for the European Commission, europa.eu.int/comm/enterprise/entrepreneurship/green_paper/literature_survey _2002.pdf (last accessed May 2006).

Audretsch, D.B. (2004) 'Entrepreneurship policy and the strategic management of places', Knowledge Clusters and Entrepreneurship in Regional Economic Development Conference, University of Minnesota, 13 September.

Aydalot, P. (1986a) 'L'aptitude des milieux locaux â promouvoir l'innovation', in J. Federwich and G.H. Zoller (Eds.) Technologie nouvelle et ruptures régionales, París: Economica.

Aydalot, P. (Ed.) (1986b) Milieux innovateurs en Europe, París: Gremi.

Camagni, R. (1991) 'Local milieu, uncertainty and innovation networks: towards a new dynamic theory of economic space', in R. Camagni (Ed.) Innovation Networks: Spatial Perspectives, Londres: Belhaven Press.

Camagni, R. and Capello, R. (1999) 'Innovation and performance of SMEs in Italy: the relevance of spatial aspects', in M.M. Fischer, L. Suárez-Villa and M. Steiner (Eds.) Innovation, Networks and Localities, Berlín: Springer.

Castells, M., Tubella, I., Sancho, T., Díaz de Isla, I. and Wellman, B. (2003) La societat xarxa a Catalunya, Barcelona: Editorial UOC i Rosa dels Vents.

Cowling, M. (2003) 'Productivity and corporate governance in smaller firms', Small Business Economics, Vol. 20, pp.335-344.

EdAS (2004) 'Anàlisi del grau de supervivència de les empreses usuàries del viver d'empreses de Barcelona Activa (1998-2003)', Espai d'Anàlisi Social, SLL. 
Feldman, M., et al. (2005) 'Creating a cluster while building a firm: entrepreneurs and the formation of industrial clusters', Regional Studies, Vol. 39, No. 1, pp.129-141.

Galende del Canto, J. and de la Fuente, J.M. (2003) 'El proceso de innovación de la empresa española: Identificación de patrones de innovación', Revista Cuadernos de Economía y Dirección de Empresas (CEDE), Vol. 16, pp.145-174.

Garson, D. (n.d.) 'Multivariate analysis for applied social science', http://www2.chass.ncsu.edu/ garson/pa765/statnote.htm (last accessed January 2007).

Garson, D. (2006) 'Statnotes: an introduction to multivariate analysis', http://www .statisticssolutions.com/ (last accessed 9 January 2007).

Global Entrepreneurship Monitor (2006) Cataluña Informe, Barcelona: Institut d'Estudis Regionals i Metropolitans de Barcelona.

Gnyawali, D.R. and Fogel, D.S. (1994) 'Environments for entrepreneurship development: key dimensions and research implications', Entrepreneurship: Theory and Practice, Vol. 18.

Gómez, L. (2002) 'Evaluación del impacto de las incubadoras de empresas: estudios realizados', Pensamiento \& Gestión, No. 13, pp.1-22.

Heerwegh, D. and Loosveldt, G. (2006) 'An experimental study on the effects of personalization, survey length statements, progress indicators, and survey sponsor logos in web surveys', Journal of Official Statistics, Vol. 22, No. 2, pp.191-210.

Lockett, A., et al. (2005) 'The creation of spin-off firms at public research institutions: managerial and policy implication', Research Policy, Vol. 34, No. 7, pp.981-993.

Löfsten, H. and Lindelöf, P. (2003) 'Determinants for an entrepreneurial milieu: science parks and business policy in growing firms', Technovation, Vol. 23, No. 1, pp.51-64.

Maillat, D. (1988) 'La revitalisation des régions de tradition industrielle: le rôle des PME et du milieu', Revue International PME, Vol. 1, No. 1.

Maillat, D. (1992) 'La relation des entreprises innovatrices avec leur milieu', in D. Maillat and J.C. Perrin (Eds.) Entreprise innovatrices et développement territorial, Neuchâtel, França: Gremi-Ires.

Maillat, D. and Lecoq, B. (1992) 'New technologies and transformation of regional structures in Europe: the role of milieu', Entrepreneurship \& Regional Development, Vol. 4, pp.1-20.

Ministerio de Educación y Ciencia (2005) Datos básicos del sistema universitario español. curso 2005/2006, Madrid: Secretaría General Técnica, Subdirección General de Información y Publicaciones, http://www.mec.es/files/datos0506.pdf (last accessed April 2006).

Minniti, M. (2005) 'Entrepreneurship and network externalities', Journal of Economic Behavior and Organization, Vol. 57, No. 1, pp.1-27.

Muller, C. and Fujiwara, T. (2003) 'The entrepreneurial environment for biotech start-ups in Germany and Japan', International Journal of Biotechnology, Vol. 5, No. 1, pp.76-94.

Ontiveros, E., Rojas, A., Serrano, B. and Amor, A. (2005) Innovación y capacidad para emprender: diagnóstico de la situación en España y líneas de acción, Madrid: Indra Sistemas, Analistas Financieros.

Porter, M.E. (1990) The Competitive Advantage of Nations, New York: Free Press.

Porter, M.E. and Stern, S. (2001) 'Innovation: location matters', MIT Sloan Management Review, Vol. 42, No. 4, pp.28-36.

Solé, P.F. (1987) 'Barcelona Activa: un projecte on la UPC ofereix gestió i coneixements tecnològics', Butlletí de la UPC, pp.2-10.

Ucbasaran, D., Westhead, P. and Wright, M. (2006) 'Entrepreneurial entry, exit and re-entry: the extent and nature of opportunity identification', Discussion Papers on Entrepreneurship, Growth and Public Policy 0906.

Urbano, D. (2005) La creació d'empreses a Catalunya: organismes de suport i actituds cap a l'activitat emprenedora, Barcelona: Col·lecció d'estudis del CIDEM i Departament de Treball i Indústria, Generalitat de Catalunya. 
Vilaseca, J. (Dir.) (2003) 'ICTs and transformations in Catalan companies', CIDEM, Generalitat de Catalunya, http://www.cidem.com/cidem/binaris/ICTs_tcm48-12617.pdf (last accessed May 2006).

Wagner, J. and Sternberg, R. (2004) 'Start-up activities, individual characteristics, and the regional milieu: lessons for entrepreneurship support policies from German micro data', The Annals of Regional Science, Vol. 38, No. 2, pp.219-240.

\section{Notes}

1 In 2005 Euros, these figures would be, respectively, 18.919 EUR and 16.930 EUR (authors' own estimation, based on the agreements of wage increments published at the Catalan Statistical Office, www.idescat.net).

2 All variables in the three models are dummy variables. Weights are calculated as the standardised parameters of a lineal regression through the origin of the precedent variables on the variable to which they are connected with an arrow (Garson, n.d.; Garson, 2006). Computations were made with SPSS 13.0.1. 